\title{
A Need Analysis for ESP-content Materials for Accountancy Programme at Vocational High School
}

\author{
Semi Sukarni \\ Universitas Muhammadiyah Purworejo \\ \{semi.sukarni24@gmail.com\}
}

\begin{abstract}
The objective of the study is to explore the need of English teachers for ESP-content materials for Accountancy Programme for Vocational High School /SMK. To collect the data, a questionnaire was constructed and distributed to the English teachers who taught English at Accountancy Programme at SMK in Purworejo and Wonosobo. There were eight teachers participated in this study. The result of the study shows that most SMK used Bahasa Inggris SMA/MA/SMK/MAK textbook which was published by Pusat Kurikulum dan Balitbang Kemendikbud which contained General English and its quality was only quite good as there were some weaknesses. All teachers in the study badly need ESP-content English materials in their English textbook as it is related to the lack of several aspects in the textbook which they use at present.
\end{abstract}

Keywords: Accountancy, ESP, need analysis , SMK

\section{INTRODUCTION}

Indonesia has the biggest workforce among ASEAN country members. These workforce have to compete with people in other countries. To be able to win the job competition the potential workers must have good skills both hard and soft skills and good communication skills. The need for effective and meaningful communication in a workplace is completely needed for the Indonesian workforce.

The vocational school graduates often lose in job competition, or even they have no courage to apply for a job vacancy because they were not good in English skills. Some companies like Garuda Airlines offer job vacancy by requiring applicants to have TOEIC score more than 400 and even some companies set with TOEIC 450 and fluent in English both oral and written. To be able to obtain fluent English skills, students must be taught with appropriate materials and instructions. Suitable and relevant materials needed in a potential workplace context make students interested in learning English and might raise their motivation to acquire the skills. An assumption underlying this approach was that the clear relevance of the English materials to their needs would improve the learners' motivation and thereby learning becomes better and faster [1]

However, the fact shows that the textbooks of vocational school have no different from textbooks for senior high school which only contained General English. There have no supplement materials to enrich vocational school students which are more related to the prospective profession like being accountant, secretary, etc.

The materials contained in the textbook for vocational schools only general English. As the materials are not relevant and match with the students' interest, the students often uninterested 
and lack of motivation to learn English. This often make the English teachers confuse about seeking out for other materials which are more relevant to the students. However, not all teachers are willing to find other materials, they only taught the students the materials contained in the textbook.

As the teachers only taught General English (GE), the students' English skills are not satisfying, they only learned written texts, understanding them without paying attention to the spoken skills. Vocational High School graduates were often lack of confidence to speak English in front of the public, particularly if the job seekers required interview in English. These problems need a solution. One of the solution is by designing ESP-based syllabus which contained materials which are relevant to their study major and which more related to the prospective jobs contexts.

To develop an ESP-based materials, need analysis is needed. Need analysis refers to techniques and procedures for collecting information to be used in syllabus design [2] .Information need to be collected, not only on why learners want to learn the specific target language, but also about such things as societal expectations and constraints and the resources available for implementing the syllabus. Further Basturkmen (2010) explains that need analysis is the identification of language and skills which are used in determining and refining the content for the ESP course. It can also be used to assess learners and learning at the end of the course. Another description was need analysis should be concern with the establishment of communicative needs and their realization, resulting from an analysis of the communication in the target situation (Chamber as cited in [4].

According to Nunan (1990) there are type of needs analysis used by language syllabus designers, i.e. learner analysis and task analysis. First, learner analysis get information about the learner. The main question is about the purpose or purposes the learner is learning the language. The information can be used as a guide to selection of content. It can also be used by teacher to modify the syllabus and methodology so they will be more acceptable and suitable to the learners.

Second, task analysis is applied to specify and categorize the language skills required to carry out real-world communicative tasks, and often follows learner analysis which establishes the communicative purposes for which the leaner wishes to learn the language. The central question might: 'What are the subordinate skill and knowledge needed by learner in order to carry out real world communicative tasks'.

Similar to Nunan (1990), Hutchinson and Waters as cited by [5]Nation \& Macalister (2010) divide needs into target needs (what the learner needs to do in the target situation) and learning (i.e. what the learner need to do?). The analysis of target needs can look at necessities (what is necessary in the learners' use of language); lack (what do the learners lack?) and wants (what do the learners wish to learn?).

Basturkmen (2013) summarizes these analyses aimed to determine priorities, such as, which skills (reading, writing, listening, speaking), and which situations or tasks, such as speaking on the telephone or writing minutes from meetings, were more or less important in the target situation. Later the concept of needs analysis was expanded to include 'deficiency analysis' (lacks or the gap between what the learner needs to know to operate in the target situation and the learner's present language proficiency). This analysis represented the point of departure for the language-learning journey. In time 'strategy analysis' (the preferred approaches and methods in teaching and learning) p.18.

According to Richards (2001) there are some purposes of needs analysis, i.e.

(1) to find out what language skills a learner needs in order to perform particular role, such as sales manager, tour guide, or university student 
(2) to help determine if an existing course adequately addresses the need of potential students

(3) to determine which students from a group are most in need of training in particular language skills

(4) to identify a change of direction that people in a reference group feel is important.

(5) to identify a gap between what students are able to do and what they need to be able to do.

(6) to collect information about a particular problem learners are experiencing.

Further Richard (2001) mentions the users of need analysis among them are curriculum officers in the ministry of education, who wish to use the information to evaluate the adequacy of existing syllabus, curriculum, and materials; teachers who will teach from the new curriculum; learners, who will be taught from the curriculum; writers who are preparing new textbooks; testing personnel, who are involved in developing assessment; staff of tertiary institution, who are interested in knowing what the expected level will be and what problem thy face.

English for Specific Purpose (ESP) is needed in addition to general English for students at vocational schools. ESP is based on designing courses to meet the learners' needs ( Huthison \& Waters, 1991). Further, they explained that ESP had focused on language at sentence level, the second phase of development shifted attention to the level above sentence, as ESP became closely involved with the emerging field of discourse or rhetorical analysis.

ESP has function to help language learners to develop the competencies needed to function in a discipline, profession or workplace (Basturkmen, 2006, p. 6). Day and Krzanowski (2011) assert that in ' $\mathrm{P}$ ' in ESP, always a professional purpose- a set of skills that learners currently need in their work or need in their professional career. In line with Day and Krzanowski (2011), Goldsmith, Riggle, Schiffrin, Tannen, \& Hamilton, (2013) present that the key feature of an ESP course is that the content and aims are oriented to the specific needs of the learners. And the key issue for teaching ESP are how to identify learner needs, the nature of genres that learners need to be able to produce as well as participate in, and how we can know that our learners have been able to do this successfully, if not, what we can do to help them to do this.

People often mix between curriculum and syllabus. Curriculum has wider scope than syllabus. Candl as cited by Nunan (1990) states that curriculum is concerned with making general statement about language learning, learning purpose, learning experience, evaluation, and the role relationships of teachers and learners. Whereas, syllabus are more localized and the based on accounts and records of what actually happens at the classroom level as teachers and learners apply a given curriculum

Syllabus design is seen as being concerned essentially with the selection and grading of content, while methodology is concerned with the selection of learning tasks and activities. Various syllabus components which need to be considered in developing language courses is Threshold Level English (van Ek 1975). Van Ek as cited in Nunan (1990) describes components of a language syllabus includes the situations in which the foreign language will be used; the language activities in which the learner will engage; the language functions which the learner will fulfil; what the learner will be able to do with respect to each topic; the general notions which the learner will be able to handle; the specific (topic-related) notions which the learner will be able to handle; the language forms which the learner will be able to use; and the degree of skill with which the learner will be able to perform.

Reviewing on related previous study, first which was done by [10] Kusni, Syamwil and Refnaldi (2014) aimed at describing a research finding on critical thoughts of English for vocational students in 2013 curriculum viewed from the theories the theories of the ESP. Sixty students of two vacational school namely Engineering and Accounting. The finding showed that English subject for the vocational schools presently was General English not 
ESP. This finding implied that English vocational schools should be carefully redesigned and reconsidered before it is widely used throughout the nation. Second study was done by [11]Suyadi (2015) with aimed at improving teaching English material for accounting program which is needed by students at university level. Target needs and learning needs questionnaire was used to get the data. The finding revealed that the students needs a specific material which has tight relationship with their study program. English skills are need to be combined with the knowledge target of accounting especially reading for enriching their vocabularies in accountancy. The third study was conducted by[12] Kardijan, Emzir and Rafli (2016) which aimed to reveal the gap between English language communicative competence required by students of the hospitality department and English learning program provided at Vocational High School 1 Tasikmalaya. The finding showed inconsistency between learning need and teaching-learning process. This prompts a reinstructional design of English for hosptality specific purposes program. It recommended both the instructional design and the professional development of ESP teachers to address understanding the gap identified, to enable students to communicate more effectively with the English at the workplace.

Based on the three studies they showed the importance of ESP- the English materials which related to the graduates' future jobs. And they also showed the urgency of developing ESP-based materials to support the General English to provide more learning experience. Based on the background of the study and the review of related research, the objectives of the study include (1) what textbooks are used by English teachers at SMK of Accountancy Programme at present and their quality; (2) to what extent the teachers need an ESP-based textbook for Accountancy Programme.

\section{METHODOLOGY}

The research belongs to qualitative research. It also belongs to exploratory research as the researcher explored the information about needs, lacks and wants as it called by need analysis. The result is used to develop a new syllabus and finally a new textbook.

This study was conducted at the chosen SMK in Purworejo and Wonosobo Regencies of Central Java. The participants were eight English teachers who taught English at Accountancy Programmme with the working experience about $15-20$ years.

Questionnaire was used to collect the data about the need analysis viewed from teachers. The questions in the questionnaire covers both closed-ended and open-ended questions. An open-ended question requires participants in any way that they please and provide primarily qualitative data. On the other hand, closed-ended question requires participants to choose limited number of responses which are predetermined by the researcher and it primarily provides quantitative data Johnson and Christensen, 2012, p. 169). There were 12 Likert-scale items to obtain the data on lack and 1 item on need and three items lopen-ended questions. A four-point Likert scale includes Strongly Agree, Agree, Disagree, and Strongly Disagree.

Thematic data analysis was used to analyze the qualitative data about the teachers' needs for ESP-content based teaching materials. Descriptive quantitative data was used to analyze the quantitative data by using descriptive statistics in a form of simple percentage calculation for the item analysis. 


\section{FINDING AND DISCUSSION}

\section{a. The present textbooks used by English teachers in Accountancy Programme at SMK and their quality}

Based on the data analysis from the questionnaire which were given to the English teachers who taught Accountancy programme at SMK, the text books which are used at present namely Bahasa Inggris SMA/MA/SMK/MAK written by Kementrian Pendidikan dan Kebudayaan; Forward an English Course for Vocational School Students written by Shyla K Laude \& Eka Mulya Astuti; Bahasa Inggris written by Mahrukh Bashir, M.Ed. Only one book which is written specifically for SMK students, while other books are still general. Although Forward an English Course for Vocational School Students contains ESP for SMK, there is no specific program whether for office administration, accountancy or marketing programme.

Based on the question about textbook quality, only one book is considered good (Bahasa Inggris). However, the other two books, one is considered quite good and the other is a bit good. For more detail analysis about the quality of the textbook is presented in the table below. The table consists of questions and four- type response in initial letter CA for Completely Agree, A for Agree, D for Disagree and CD for Completely Disagree.

Table 1. Questionnaire result of teachers' response of textbook quality

\begin{tabular}{|c|c|c|c|c|c|}
\hline \multirow[t]{2}{*}{ No } & \multirow[t]{2}{*}{ Statement } & \multicolumn{4}{|c|}{ Teacher Response (\%) } \\
\hline & & C & A & $\mathrm{D}$ & $\mathrm{CD}$ \\
\hline 1 & $\begin{array}{l}\text { English Textbooks for SMK in general relevant } \\
\text { to the students' need of English }\end{array}$ & 0 & 0 & 100 & 0 \\
\hline 2 & The Exposure in textbook very relevant. & 0 & 0 & 100 & 0 \\
\hline 3 & $\begin{array}{l}\text { The content of vocabulary in textbook is } \\
\text { relevant to the students' skill }\end{array}$ & 0 & 0 & 100 & 0 \\
\hline 4 & $\begin{array}{l}\text { The content of grammar related to the students' } \\
\text { skill. }\end{array}$ & 0 & 0 & 100 & 0 \\
\hline 5. & $\begin{array}{l}\text { Communicative expressions in textbook is } \\
\text { related to the students' skill }\end{array}$ & 0 & 25 & 75 & 0 \\
\hline 6 & $\begin{array}{l}\text { Reading text in textbook is related to the } \\
\text { students' skill }\end{array}$ & 0 & 25 & 75 & 0 \\
\hline 7 & $\begin{array}{l}\text { Context for speaking practice in textbook is } \\
\text { related to the students' skill. }\end{array}$ & 0 & 0 & 100 & 0 \\
\hline 8 & Textbooks contain various learning activities. & 0 & 37.5 & 62.5 & 0 \\
\hline 9 & $\begin{array}{l}\text { Learning activities provided make students } \\
\text { participate actively. }\end{array}$ & 0 & 0 & 100 & 0 \\
\hline 10 & $\begin{array}{l}\text { Textbooks contain various evaluation types } \\
\text { including authentic assessment. }\end{array}$ & 0 & 37.5 & 62.5 & 0 \\
\hline 11 & $\begin{array}{l}\text { Textbooks stimulate students to learn English } \\
\text { according to their skill. }\end{array}$ & 0 & 0 & 100 & 0 \\
\hline
\end{tabular}

Based on table 1, there are two response categories: the first 100 percent „Disagree “ and the second majority „Disagree“. The first, there are six aspects of textbook quality which are completely not in favor with the teacher wishes, name questions 1, 2, 3, 4, 7 and 9. English textbooks for SMK generally are not relevant to the students' need of English; the exposure in textbook are not very relevant; the content of vocabulary in textbook are not very relevant to the students' skill; content of grammar are not related to the students' skill; all teachers believed that context for speaking practice in textbook is unrelated to the students' skill and learning activities provided in the textbooks do not make students participate 
actively. The second, majority teachers Disagree with question 5, 6, 8 and 10 . Communicative expressions in textbook are not related to the students' skill; texts in the textbooks are not related to the students' skill; majority teachers believed that textbooks do not contain various learning activities; and textbooks do not contain various evaluation types including authentic assessment. In other words, the traditional evaluation types dominate the textbooks.

From the textbook analysis as become the lack in need analysis shows that the quality of the published textbooks in the market which are used at present are not good. As there are some weaknesses like irrelevant with the students' skills in terms of vocabulary, context, grammar, functional expression, reading texts; lack of relevant exposure, less various evaluation types, less learning activities, unstimulated learning activities. This finding support the earlier studies which were conducted by Kusni, Syamwil and Refnaldi (2014) that the government needs to reconsider about the content of English syllabus and textbook for Vocational High School.

\section{b. Teachers' ${ }^{6}$ need of ESP-content based English materials in their English textbook}

There are two questions to get the data of the research problem. First, close-ended question and open-ended question. The close-ended question is question 12 in the questionnaire. Question 12: In your opinion, it needs to publish textbook which contained English for Specific Purpose /ESP for Accountancy Programme for Vocational High School Students. Seventy five percent teachers' response was "Completely Agree" 25 percent was "Agree". To make it clearer, the response is presented in the chart below.

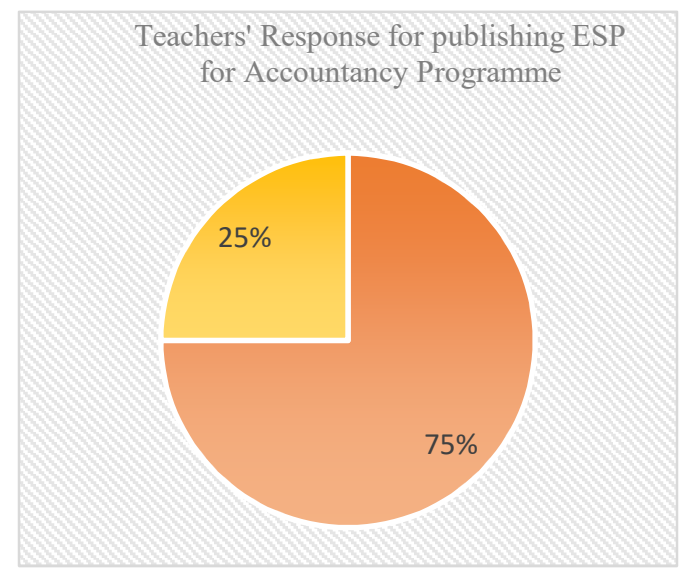

Fig. 1. Teachers' Response for publishing ESP for Accountancy Programme

Figure 1 shows that all teachers badly need ESP-content based English materials in their English textbook. It is related to the lack of several aspects in the textbook which they use at present. They concern about giving the relevant material which are needed by the students in the prospective workplace. The English teachers think and worried if the students only get general English the graduates' skill might not match with the required language skills needed in the potential workplace. It means that to publish English for Specific Purpose/ESP for Accountancy Programme for Vocational High School students become the solution for the weakness of the published textbooks. 
The second is open-ended question: „According to you, is it necessary to publish textbooks contained ESP: English for Accountancy Programme for Vocational High School Students? Please give the reasons"!

The responses from the eight English teachers is presented below.

Teacher 1: Yes, so that the students are familiar with the vocabulary which is relevant with the accountancy skill competence.

Teacher 2: Yes, so that the students are familiar with the vocabulary which will be used in the job field based on skill competence.

Teacher 3: It really necessary, because it can support the students' competence and relevant with the skill which the student learn.

Teacher 4: Yes. To provide students English skills based on their competence.

Teacher 5: Yes So that the students are accustomed with using vocabulary which are used workplace based on their accountancy skill competence.

Teacher 6: Yes. A book which is suitable with Vocational High School (VHS) and students * skill competence.

Teacher 7: Yes, I absolutely agree with publishing the new textbook which is suitable with and students 'skill competence.

Teacher 8: No, it is unnecessary because the materials in national examination or English tests often general.

Based on the most teachers' response to the question above publishing textbooks contained ESP: English for Accountancy Programme for Vocational High School students is really necessary. The English teachers have good expectation from the new English textbook which is developed from ESP-based syllabus. It is expected that the graduates will have better English skills which are more related and matched with the skills required in the potential workplace. Only one teacher oppossed against the opinion of the most teachers about publishing an ESPcontent textbook. This finding supports the previous study done by Suyadi (2015) that ESP content textbook for Accountancy programme is needed for students as well as the teacher to provide the graduates to be familiar with vocabulary, situation and context in more closely to their future work.

\section{CONCLUSION}

Based on the finding and discussion, the conclusion is made as follows. After analyzing the response in open-ended questions, teachers demand of publishing textbooks contain ESP: English for Accountancy Programme for Vocational High School students is really necessary. The English teachers have good expectation from the new English textbook which is developed from ESP-based syllabus. It expected that the graduates will have better English skills for communication which are more related and matched with the skills required in the potential workplace.

Based on the need analysis the lack in textbook analysis shows that the quality of the published textbooks in the market which are used at present by SMK are not good. As there are some weaknesses like irrelevant with the students' skills in terms of vocabulary, context, grammar, functional expression, reading texts; lack of relevant exposure, less various evaluation types, less learning activities, and unstimulated learning activities.

Related to the need in the need analysis it shows that all teachers badly-need ESP-content based English materials in their English textbook. They were concerned about the lack of several aspects in the textbook which they use at present. They are eager to give the relevant materials which are needed by the students in the prospective workplace. 
Based on the response analysis in open-ended questions, teachers demand of publishing textbooks contained ESP: English for Accountancy Programme for Vocational High School students. The English teachers have good expectation from the new English textbook which is developed from ESP-based syllabus. It is expected that the graduates will have better English skills for communication which are more related and matched with the skills required in the potential workplace.

The result of the study implied that the governments or private institution should develop the ESP-based textbooks in advance which is based on a more detail need analysis to overcome the lack of the English textbook used at present and to fulfill the students' need of English skills which are necessary in their future job.

\section{References}

[1] J. \& Day and Krzanowski, Teaching English for Specific Purposes: An Introduction. Singapore: Cambridge University Press, 2011.

[2] D. Nunan, Syllabus Design. University Press, 1990.

[3] H. Basturkmen, Developing Courses in English for Specific Purpose. New York: Palgrave Macmillan, 2010.

[4] H. Basturkmen, "Needs Analysis and Syllabus Design for Language for Specific Purposes," Encycl. Appl. Linguist., pp. 1-8, 2013.

[5] I. S. P. Nation and J. Macalister, Language Curriculum Design. London: Routledge, 2010.

[6] Richards, Curriculum Development in Language Teaching. Cambridge: Cambridge University Press, 2001.

[7] Huthison and \& Waters, English for Specific Purposes. New York: Cambridge University Press, 1991.

[8] H. Basturkmen, Ideas and Option in English for Specific Purposes. London: Lawrence Erlbaum Associates, 2006.

[9] J. A. Goldsmith, J. Riggle, D. Schiffrin, D. Tannen, and H. E. Hamilton, The Handbook of English for Specifi c Purposes Blackwell Handbooks in Linguistics. West Sussex: WileyBlackwell, 2013.

[10] Khusni, Syamwil, and Rifnaldi, "Diagnosing the Need for English at Vocational School : Redesign the Curriculum 2013?," 2014, no. 1988, pp. 4-5.

[11] Suyadi, "English for Specific Purposes for Accountancy Students," no. 3, pp. 467-473, 2015.

[12] D. Kardijan, Emzir, and Zaenal Rafli, "The Gap Between Learning Need and its Implementation in English for Hospitality Specific Purposes Program," vol. 6, no. 1, pp. 125-136, 2017.

[13] Jonhson, B \& Christensen, L. Educational Research Quantitative, Qualitative and Mixed Method. Singapore. SAGE Publications Asia-Pacific. 2012. 